\title{
Role of Aloe Vera Ksharasutra in the Management of Arsha: A Case Study
}

Available online at www.ijistweb.com

\section{CASE STUDY}

\author{
Dharmpal T. Patil*1 ${ }^{1}$, P. Hematha Kumar ${ }^{2}$
}

${ }^{1} \mathrm{Ph}$. D. Scholar (Shalya), Ayurveda Department, Tilak Maharshtra Vidyapeeth, Pune, India.

${ }^{2}$ Prof. and H.O.D., P.G. Dept. Shalya, National Institute of Ayurveda, Jaipur, India.

*Corresponding Author's E-mail: patildharmapal@gmail.com

\begin{abstract}
Arhsa (Haemorrhoids) is one of the serious major anorectal diseases affecting large number of world population. Arhsa can be manage by various para-surgical measures of ayurveda such as; Agnikarma, Ksharakarma \& Ksharasutra. Generally Snuhikshira Ksharasutra employed for ligation purpose but it also suffers with some adverse effect such as; pain, irritation and burning sensation. Therefore it was required to evaluate efficacy of some other Ksharasutra in the management of Arhsa. Considering this fact present study was carried out to measure efficacy of Aloe vera Ksharsutra in the management of Arsha. Study observes reduction in clinical symptoms such as pain, irritation and burning sensation after ligation with Aloe Vera Ksharasutra. Two patients were included in the study and one patient was treated with Aloe vera Ksharsutra ligation while other was treated with Snuhi Kshira Ksharsutra ligation. Study observed that Aloe Vera Ksharasutra ligation offers relief in pain and burning sensation. Reduction in discharge was also observed with Aloe vera Ksharsutra as compared to Snuhi Kshira Kasharasutra. The present finally concluded that there is a need of further study on large population to establish results of current study.
\end{abstract}

Keywords: Arsha, Aloe Vera Ksharasutra, Snuhi Kshira Ksharsutra, Ligation, Haemorrhoids.

\section{Introduction}

Anorectal disorders are very painful pathological condition affecting quality of life and incidences of these diseases increases day by day due to the adverse effect of current life style. Anorectal disorders are embarrassing for patient since these disorder affect anal region of body. Arsha is one of the anorectal disorder also termed as 'Durnam' in Bhaishajyaratnavali,(1) while Yogaratnakara has defined Arsha as Mansakalika which obstructs Gudamarga (2). Ayurveda classified different types of Arsha including; Vataja, Pittaja, Kaphaja, Sannipataja, Raktaja and Sahaja $(3,4)$. Various factors may leads Arsha such as; sedentary life style, irregular diet, physiological disturbances, anxiety, consumption of junk food and lack of exercise. Ayurveda also described some other factors for Arsha including cold water, continuous seating \& riding, suppression of normal urge of micturition \& defecation (5).

Haemorrhoids are abnormal mass of dilated engorged blood vessels occurs internally in the anal canal or around the anus (6). Haemorrhoids may be classified as per their location i.e; external, internal and intero-external haemorrhoids. According to prolapse it may also divided into four category; first degree, second degree, third degree and fourth degree (7). According to $\mathrm{WHO} 40 \%$ of people suffer from Haemorrhoids globally and (8).

Sushruta described that Kshara is standard procedure for managing anorectal problems since it possesses qualities like; Chhedana (Excision), Bhedana (incision and drainage) and Lekhana (scraping) etc (9). Ashtanga Hridaya mentioned that Kshara is easily applicable even perform when Agnikarma and Shashtrakarmas are contraindicated. Ksharachikitsa is considered important approach for the management of Arsha by almost all ayurveda classic (10-12). Various study proved efficacy of Ksharasutra treatment, however standardization on Ksharasutra is still need for ligation procedure $(13,14)$.

The ancient text of ayurveda clarifies that Ksharasutra ligation procedure offers radical curing property in Arsha due to its herbochemical cauterization effect. Considering these all facts the present research work was planned to evaluate effect of Aloe Vera Ksharasutra ligation in the management of Arsha. 


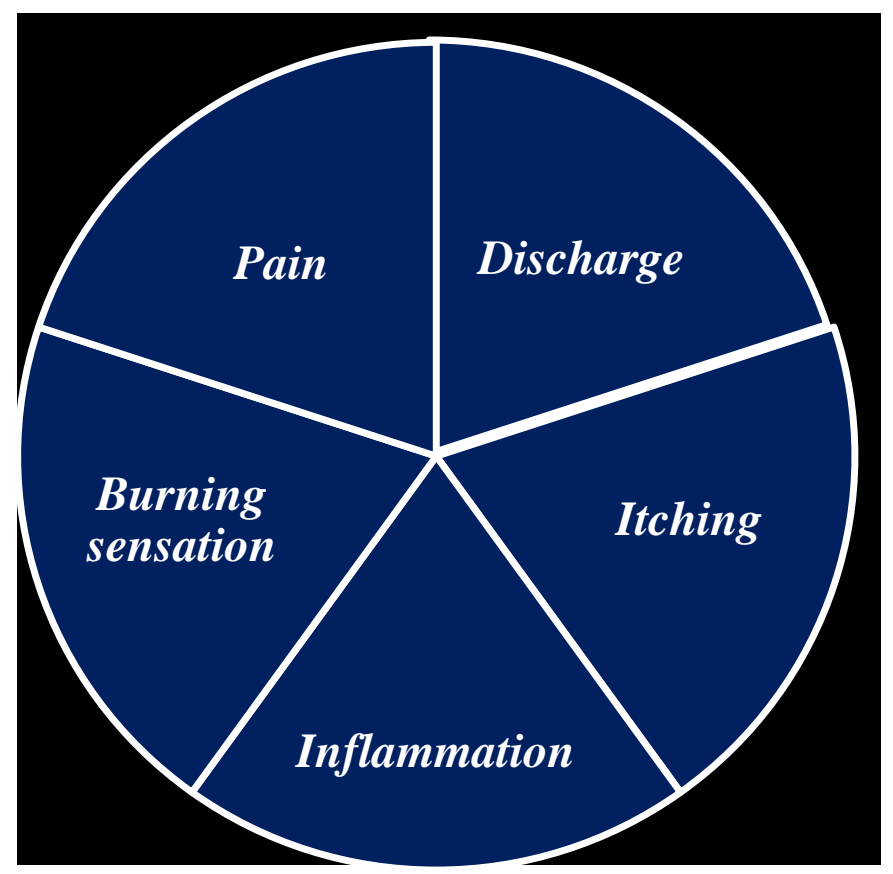

Figure 1. General symptoms of Arsha

\section{Material and Methods}

\section{Objectives}

- To evaluate the effect of Aloe Vera Ksharsutra on sign and symptoms of Arsha.

- To compare the effect of Aloe Vera Ksharsutra against Snuhi Kshira Ksharsutra with respect to specific symptoms of Arsha; pain and burning sensation.

\section{Study protocol}

The present case study was carried out in two diagnosed patients of Arsha. One patient was treated with Aloe Vera Ksharsutra ligation while another patient was treated with Snuhi Ksheera Ksharsutra ligation. Patients were observed on alternate days up to 9 days.

\section{Drug review}

Kumari, Apamarga and Haridra were used to prepare Aloe Vera Ksharsutra while Snuhikshira Kshar Sutra was prepared by using Snuhi Kshir, Apamarga and Haridra. Table 1 presented ayurveda properties of these ingredients.

Table 1 Description of Kshar Sutra ingredients

\begin{tabular}{|c|c|c|c|c|c|c|}
\hline Drug name & Rasa & Vipaka & Virya & Guna & Dosha Karma & Karma \\
\hline $\begin{array}{l}\text { Kumari } \\
(\text { Aloe } \\
\text { Vera })^{15}\end{array}$ & $\begin{array}{l}\text { Tikta- } \\
\text { Madhur }\end{array}$ & Madhur & Sheeta & $\begin{array}{l}\text { Guru, } \\
\text { Snigdha } \\
\text {, Picchil }\end{array}$ & Tridoshaghna & $\begin{array}{l}\text { Vedanasthapana, } \\
\text { Shothahar, } \\
\text { Vranashodhan, } \\
\text { Ropana, Deepana, } \\
\text { Pachana, Bhedana, } \\
\text { Balya, Bruhan }\end{array}$ \\
\hline $\begin{array}{l}\text { Snuhi } \\
\text { (Euphorbia } \\
\text { nerifolia) }\end{array}$ & $\begin{array}{l}\text { Katu, } \\
\text { Tikta }\end{array}$ & Katu & Ushna & $\begin{array}{l}\text { Laghu, } \\
\text { Ruksha }\end{array}$ & $\begin{array}{l}\text { Kapha } \\
\text { Vataghna }\end{array}$ & $\begin{array}{l}\text { Lekhan, } \\
\text { Vedanasthapana, } \\
\text { Shothahar, } \\
\text { Raktashodhana, } \\
\text { Vishaghna }\end{array}$ \\
\hline $\begin{array}{l}\text { Apamarga( } \\
\text { Achyranthu } \\
\text { s aspera })^{\mathbf{1 7}}\end{array}$ & $\begin{array}{l}\text { Katu, } \\
\text { Tikta }\end{array}$ & Katu & Ushna & $\begin{array}{l}\text { Laghu, } \\
\text { Ruksha }\end{array}$ & $\begin{array}{l}\text { Kapha- } \\
\text { Vataghna }\end{array}$ & $\begin{array}{l}\text { Deepana, Pachana, } \\
\text { Vatanulomana, } \\
\text { Kaphavilayan, }\end{array}$ \\
\hline
\end{tabular}




\begin{tabular}{|l|l|l|l|l|l|}
\hline & & & & & $\begin{array}{l}\text { Srotorodhnashak, } \\
\text { Mootral, } \\
\text { Vishaghna }\end{array}$ \\
\hline $\begin{array}{l}\text { Haridra } \\
\text { (Curcuma } \\
\text { longa) }\end{array}$ & Tikta,
\end{tabular}

\section{Method of preparation Ksharsutra}

Aloe Vera Ksharasutra and Snuhi Kshir Ksharsutra were prepared according to Ksharsutra method described in Sushruta

Table 2 Method of preparation of Aloe Vera Ksharasutra

\begin{tabular}{|c|c|c|c|}
\hline S. No. & $\begin{array}{l}\text { Ingredients combination for Aloe } \\
\text { Vera Ksharasutra }\end{array}$ & No. of coatings & Total coatings \\
\hline 1 & Aloe vera & 11 & \multirow[t]{3}{*}{21} \\
\hline 2 & Aloe vera + Apamarga Kshara & 7 & \\
\hline 3 & Aloe vera + Haridra Churna & 3 & \\
\hline S. No. & $\begin{array}{l}\text { Ingredients combination for Snuhi } \\
\text { Kshira Ksharasutra }\end{array}$ & No. of coatings & Total coatings \\
\hline 1 & SnuhiKshira & 11 & \multirow[t]{3}{*}{21} \\
\hline 2 & SnuhiKshira + ApamargaKshara & 7 & \\
\hline 3 & SnuhiKshira + HaridraChurna & 3 & \\
\hline
\end{tabular}

\section{Method of Ligation of Ksharasutra}

Kaharasutra ligation procedure was carried out in operation theaters under aseptic condition in three phases; pre-operative, operative and post-operative (19).
Samhita and Bhaishajyaratnavali, (13, 14) ingredient combination and overall coating was described in Table 2.

Table 3 Gradation of parameters

\begin{tabular}{|c|c|c|c|}
\hline S. No. & Symptom & Description & Grade \\
\hline \multirow[t]{4}{*}{1} & \multirow[t]{4}{*}{ Pain } & No pain & 0 \\
\hline & & Dull pain and no requirement of medicine & 1 \\
\hline & & Pain requires oral medication & 2 \\
\hline & & Unbearable pain requires injectable drug & 3 \\
\hline \multirow[t]{4}{*}{2} & \multirow[t]{4}{*}{ Discharge } & No discharge/bleeding & 0 \\
\hline & & Discharge/Bleeding along with defecation only & 1 \\
\hline & & $\begin{array}{l}\text { Discharge/Bleeding in the forms of drops after } \\
\text { defecation also }\end{array}$ & 2 \\
\hline & & Continuous discharge/bleeding & 3 \\
\hline \multirow[t]{4}{*}{3} & \multirow[t]{4}{*}{ Irritation } & No irritation & 0 \\
\hline & & Irritation only during defecation & 1 \\
\hline & & Irritation on movements & 2 \\
\hline & & Continuous, unbearable irritation & 3 \\
\hline 4 & Cutting & Pile mass not cut & 0 \\
\hline
\end{tabular}




\begin{tabular}{|c|c|c|c|}
\hline & Pile mass partially cut & 1 \\
\hline & & Complete removal of pile mass & 2 \\
\hline \multirow[t]{3}{*}{5} & \multirow[t]{3}{*}{ Healing } & Unhealed wound & 0 \\
\hline & & Partially healed wound & 1 \\
\hline & & Completely healed wound & 2 \\
\hline
\end{tabular}

\section{Results and Discussion}

\section{CASE NO.1}

\section{Clinical Details of Patient}

Male patient, aged 45 years, occupation as driver having no past history of major illness.

\section{General Examination}

Pulse - 78/min, BP - 130/80 mm of Hg, Weight - 76 kg, Prakriti - Vata-Kapha, Agni - Vishama, Koshtha-Krura.

\section{Samprapti Ghatak: $(20,21)$}

Dosha: Apana Vayu, Pachak Pitta, KledakKapha

Dushya: Tvak, Rasa, Rakta, Mansa, Meda

Strotas: Annavaha, Purishavaha, Raktavaha

Udbhavasthana: Aampakvashaya

Adhishthan: Gudavalis

Vyadhimarga: Abhyantar

Diagnosis: Abhyantara Arsha (Haemorrhoids III $^{\text {rd }}$ degree)

Treatment Given: Aloe Vera Ksharsutra ligation.

\section{CASE NO. 2}

\section{Clinical Details of Patient:}

Male patient, aged 51 years, occupation as shopkeeper, having no past history of major illness.

\section{General Examination:}

Pulse $-74 / \mathrm{min}$, BP $-120 / 80 \mathrm{~mm}$ of $\mathrm{Hg}$, Weight - 71 kg, Prakriti - Kapha-Vata, Agni - Tikshna, Koshtha-Krura.

Table 4 Effect of Aloe Vera Ksharasutra
Samprapti Ghatak: (20,21)

Dosha: Apana Vayu, Pachak Pitta \& Kledak Kapha.

Dushya: Tvak, Rasa, Rakta, Mansa \& Meda.

Strotas: Annavaha, Purishavaha \& Raktavaha.

Udbhavasthana: Aampakvashaya.

Adhishthan: Gudavalis.

Vyadhimarga: Abhyantar.

Diagnosis: Abhyantara Arsha (Haemorrhoids III $^{\text {rd }}$ degree).

Treatment: Snuhi Kshira Ksharsutra ligation.

\section{Effect of Therapy}

Study observed that both patients received good relief in sign \& symptoms of disease; pain, discharge \& irritation were found to be absent while cutting and healing also observed in both cases. Aloe Vera Ksharsutra was found more effective than Snuhikshira Ksharsutra in terms of reduction in severity of symptoms such as; pain, discharge and irritation. Cutting was observed more rapid by Snuhikshira Ksharsutra thus it may be advise that Arsha can be successfully treated with Aloe Vera Ksharsutra therapy without any adverse effect or complications.

\section{Effect of Aloe Vera Ksharasutra}

All symptoms were relieved up to good extent and healing effect was also observed while pile mass was cut on $7^{\text {th }}$ day (Table 4).

\begin{tabular}{|l|l|c|c|c|c|c|}
\hline \multirow{2}{*}{ S. No. } & \multirow{3}{*}{ Parameter } & \multicolumn{5}{|c|}{ Follow ups (Days) } \\
\cline { 3 - 7 } & & D1 & D3 & D5 & D7 & D9 \\
\hline 1 & Pain & 3 & 2 & 1 & 1 & 0 \\
\hline
\end{tabular}




\begin{tabular}{|l|l|c|c|c|c|c|}
\hline 2 & Discharge & 3 & 2 & 1 & 0 & 0 \\
\hline 3 & Irritation & 2 & 1 & 1 & 0 & 0 \\
\hline 4 & Cutting & 2 & 2 & 1 & CUT & NA \\
\hline 5 & Healing & NA & NA & NA & 1 & 0 \\
\hline
\end{tabular}

\section{Effect of Snuhi Kshira Ksharasutra}

Pain and discharge symptoms were relieved but mild irritation was observed, pile mass cut

Table 5 Effect of Snuhi Kshira Ksharasutra down and incomplete healing recorded, pile mass was cut on $5^{\text {th }}$ day.

\begin{tabular}{|l|l|c|c|c|c|c|}
\hline \multirow{2}{*}{ S. No. } & \multirow{2}{*}{ Parameter } & \multicolumn{5}{|c|}{ Follow ups (up to 5 day) } \\
\cline { 3 - 7 } & & D1 & D3 & D5 & D7 & D9 \\
\hline 1 & Pain & 3 & 2 & 2 & 1 & 0 \\
\hline 2 & Discharge & 3 & 2 & 2 & 1 & 0 \\
\hline 3 & Irritation & 3 & 3 & 2 & 1 & 1 \\
\hline 4 & Cutting & 2 & 1 & CUT & NA & NA \\
\hline \hline 5 & Healing* & NA & NA & 2 & 1 & 1 \\
\hline
\end{tabular}

\section{Rational of the study}

The Kshara Sutra ligation having acceptability due to its efficacy but still there is need of standardization of Kshara Sutra ligation procedure W.S.R. to its efficacy. Patients preferring non-surgical process of Kshara Sutra but irritability are the major drawback hence; here is a need to develop such Kshara Sutra which is less painful and less irritant. Considering this fact present study was planned to measure effect of Kshara Sutra by modifying materials of Kshara Sutra preparation.

Recently various research scholars studied effect of Kshara Sutra prepared by conventional method using Snuhi Kshira; which may be corrosive, irritant and painful to the patients. Therefore present study involve use of Aloe Vera pulp instead of the Snuhi Kshira, to overcome the problems created by the Snuhi Kshira Ksharasutra i.e. corrosive, irritant and painful. Aloe Vera possesses Sheet Viryatmak effect thus offers cutting, healing, antiseptic and antibiotic properties. Aloe Vera is easily available and may be prepared in all climates and help in the removal of piles.

\section{Mode of action of Aloe Vera Ksharasutra}

Aloe Vera Ksharasutra offers chemical cauterization which help in cutting of pile.
Ksharasutra created pressure on muscle mass which helps in cutting and healing process. The antimicrobial property of Ksharasutra prevents further chances of infection/sepsis. Aloe Vera does not affect properties of Apamarga Kshara and provides synergistic effect with Apamarga Kshara. Aloe Vera Ksharasutra having Sheet virya, Ushna and Tikshna properties which help in removing of piles without irritation as compare to Snuhi Kshara. Aloe Vera specifically possesses properties like; Shothahara, Bhedana, Vedanasthapaka and Vranaropana which removes pile-mass with minimum pain. Aloe Vera has antimicrobial effect hence chances of post removal infection decreses. The overall effect of Aloe Vera Ksharasutra was found to be satisfactory towards the management of Arsha.

\section{Limitation of study}

- This was case study and carried out in only two patients; randomized controlled clinical trials recommended further.

- Study in large representative sample from large population will provide more authentic results.

\section{Conclusion}

Finally it was concluded that Aloe Vera Ksharsutra is more effective than Snuhi Kshira 
Ksharasutra with respect to reduction in parameters such as; pain, discharge, irritation and healing. However cutting is observed more effective in Snuhi Kshira Ksharasutra. Aloe Vera Ksharasutra was found to be effective, economic, easy to prepare \& use with minimal adverse effects for the management of Arsha.

\section{Acknowledgement}

The authors are thankful to IJIST Journal for publishing their article.

\section{Conflicts of Interest}

The author declares that there are no conflicts of interest.

\section{References}

1. Ambikadatta Shastri Editor, Bhaishyajya Ratnavali of Govind Das, Arshachikitsa Prakaran, Chapter 9, Verse 1. Varanasi: Chaukhambha Sanskrit Sansthan, 2005; p. 294.

2. Laxmipati Shastri Editor, Yoga Ratnakar of Unknown Author, Arshanidan, Varanasi: Chaukhambha Sanskrit Sansthan, 2005; p. 294.

3. Anant Ram Sharma Editor, Sushruta Samhita of Sushruta (Vol. I), Nidansthana; Arshanidan Adhyaya: Chapter 2, Verse 3. Varanasi: Chaukhambha Subharati Prakashana, 2008; p. 474.

4. Ibidem 2, Arshanidan. p. 294.

5. Ibidem 3, (Vol I), Nidansthana; Arshanidan Adhyaya: Chapter 2, Verse 4. p. 474.

6. Haemorrhoids/Definition; Available from www.merriam-webster.com/dictionary/ hemorrhoid. Last accessed on 19/07/2018.
7. Haemorrhoids/Types \& Degrees; Available from http://teachmesurgery.com/general/ anorectal/ haemorrhoids/. Last accessed on 23/07/2018.

8. Haemorrhoids/Prevalence rate; Available from https://www.news-medical.net/health/ Epidemiologyof-Hemorrhoids.aspx. Last accessed on 03/08/2018.

9. Ibidem 3, (Vol I), Sutrasthana; KsharapakvidhiAdhyaya: Chapter 11, Verse 3. p. 78.

10. Ibidem 3, (Vol II), Chikitsasthana; Arshachikitsa Adhyaya: Chapter 6, Verse 3. p. 225.

11. Ibidem 1, Arshachikitsa Prakaran, Chapter 9, Verse 272-73. p. 328.

12. Vidyadhara Shukla, Ravidatta Tripathi Editors, Charaka Samhita of Charaka (Uttarardha), Chikitsasthana; Arshachikitsa Adhyaya: Chapter 14, Verse 33. Varanasi: Chaukhambha Bharati Academy, 2003; p. 329.

13. Ibidem 3, (Vol II), Chikitsasthana; Viarpanadistanrogchikitsa Adhyaya: Chapter 17, Verse 30-33. p. 307.

14. Ibidem 1, Arshachikitsa Prakaran, Chapter 9, Verse 35. p. 301.

15. Krushna Shastri Chunekar Editor, Bhavaprakash Nighantu of Bhavamishra, Guduchyadi Varga; Verse 230. Varanasi: Chaukhambha Bharati Academy, 2006; p. 419.

16. Ibidem 15, Guduchyadi Varga: Verse 76. p. 307.

17. Ibidem 15, Guduchyadi Varga: Verse 219-20. p. 414.

18. Ibidem 15, Haritakyadi Varga: Verse 196-97. p. 114.

19. Ksharasutra/Procedure of ligation; Available from www.ncbi.nlm.nih.gov/pmc/ articles/PMC3296345/. Last accessed on 15/08/2018.

20. Dr Ganesh Krishna Garde Editor, Sartha Vagbhat Marathi commentary on Ashtang Hriday of Vagbhat, Nidansthana; Arshanidan Adhyaya: Chapter 7, Verse 2. Pune: Anamol Prakashana, 1999; p. 182.

21. Ibidem 12, (Uttarardha), Chikitsasthana; Arshachikitsa Adhyaya: Chapter 14, Verse 24-25. p. 328. 